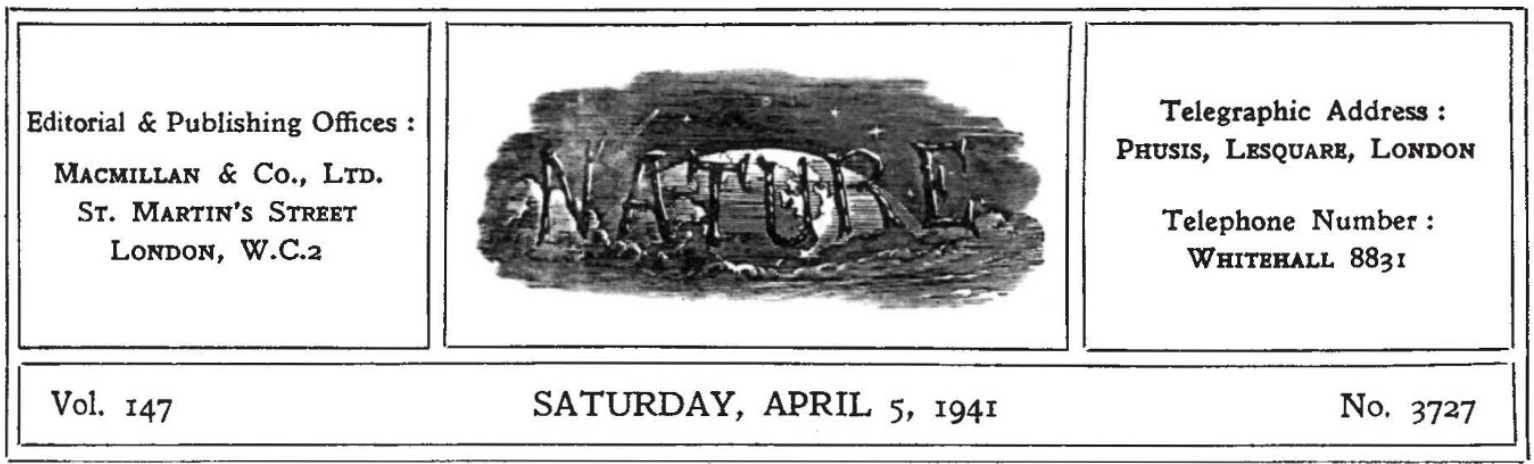

\title{
ASPECTS OF RECONSTRUCTION-I
}

$\mathrm{T}$ HE importance already attached by the Government to post-War reconstruction was seen in the changes in the machinery of government recently announced. Mr. Arthur Greenwood, the Minister without Portfolio, has now relinquished his oversight of the economic field and, while remaining in the Cabinet, has undertaken responsibility for the study of reconstruction and post-War problems. Later on, it is stated, when the end of the War can be more clearly foreseen, a ministry will be formed for this purpose. Meanwhile, Mr. Arthur Greenwood will be chairman of the group of Ministers.

In the attention which has been focused on the question of production and man-power and the effect of the changes simultaneously announced in that field, this part of the statement has been somewhat overshadowed. The statement, however, points out that the object will be to find practical solutions for the immediate problems of a transition from war to peace, and also to outline and presently to amplify a policy for the years immediately following the War which will command the support of the nation as a whole and enable united action to proceed in peace as in war. Mr. Greenwood has himself described some of the problems that he and his colleagues have specially in mind, and it is worth noting that he brings to this task the experience that he gained in the War of 1914-18. $\mathrm{He}$ was an active and resourceful member of the first Reconstruction Committee set up by Mr. Asquith's Government in 1916, and then of the Ministry of Reconstruction set up by $\mathrm{Mr}$. Lloyd George in 1917.

Mr. Greenwood has said that the country will not tolerate the spectacle of abject poverty or the curse of unemployment. Our educational system and our social services will be developed, and plans are being made to abolish ugliness and hovels in our towns. Mr. Greenwood has spoken, too, of his desire that the free spirit of man should emerge from the ruins of the War, and referred to the problem of unemployment. In remoulding our economic system it must indeed be a prime concern to preserve and increase the enjoyment of those rights and liberties that have been overthrown in the totalitarian States, and which we have entered on this struggle to uphold.

There is abundant evidence that Mr. Greenwood and his colleagues are not thinking ahead of the nation, but are giving expression to thoughts and aspirations occupying the minds of many already in the midst of their concentration on the immediate task of winning the war. The undercurrent of questionings with which Lord Reith's appointment as Minister of Works and Building was received, and the type of informed criticism which has greeted his appointment of Mr. T. S. Tait as director of standardization, show the live interest which is already taken in this question of reconstruction. Other noteworthy examples are to be seen in the address on "Trends in Nutrition" given by Sir John Orr before a meeting of the Leeds Branch of the British Medical Association last autumn, and recently published in the British Medical Journal, the fine address on "Problems of Building Reconstruction" delivered by Mr. D. E. E. Gibson, the city architect, Coventry, before the Royal Society of Arts early last December, and the admirable report of the Committee of the Town Planning Institute on Compensation and Betterment.

An outstanding discussion of the wider issues of reconstruction has been contributed to the 
Round Table of January under the title "Recon. struction : Ends and Means", which as a contribution to lucid thinking about this important matter deserves widespread attention and has real claims on the notice of scientific workers. It demonstrates why this marked growth of the readiness to reexamine the foundations of our society is timely and should be encouraged, and gives us yet another weighty reminder that, as the experience of the last Ministry of Reconstruction showed, reconstruction must be planned now or never. It is not true that the opportunity will come when the victory is won; the opportunity will then disappear. It is the fires of war that have softened the framework of our society, and we must strike while the metal is malleable if we are to determine its new shape.

There are, of course, many things that are physically unattainable in war-time, but this article in the Round Table makes once more the point that has been repeatedly urged in these columns : plans for reconstruction--provided they reflect the unity of the nation and do not disturb it -are not a hindrance to the strategists; they are a necessary part of the grand strategy of victory, both at home and abroad. In them we can take a spiritual offensive, and proving among our own people that democracy is a cause as bold and dynamic, as young and as forceful as any tyrant's 'New Order', we shall not have to coax allies to our standard.

This note, so clearly sounded in President Roosevelt's inaugural address on January 20, shows indeed where the strongest hope of enduring Anglo-American co-operation lies, and how much a bold and creative policy of reconstruction might do to secure American support in the wider task of international economic reconstruction after the War. Moreover, the article shows how little reason there is to be pessimistic about our powers of recovery or resources for reconstruction. Productive resources are unlikely to be materially reduced, and the immensely lighter toll of life which the first sixteen months of the War have claimed as compared with experience in 1914-18, to which the Prime Minister recently referred in dealing with our man-power resources, suggests that our position is likely to be stronger rather than weaker than in 1918, because the real capital of the nation, its man-power and woman-power and the moral and spiritual resources, are less impaired whatever the material destruction.

It has been suggested that at present it is the sorts of reconstruction that require clear definition rather than the sketching of any specific measures. There is anxiety that action taken in war should not, if at all avoidable, prejudice the future. Moreover, we are developing our organization and our plans for obliterating the damage due to air raids. Even this reconstruction in the literal sense of the word is not a simple job. Someone must at least decide which buildings shall be rebuilt first. Moreover, since we shall not generally have the opportunity of starting again from the beginning, the only real choice is between a good job and a bad job of patching. The need for very careful forethought and planning is accordingly all the greater, and even in this small subdivision of the whole question of reconstruction, the problems are immense and afford Lord Reith a magnificent opportunity.

To the extent of those opportunities the address of Mr. D. E. E. Gibson, already mentioned, bears striking testimony. Social and economic changes of far-reaching significance are already taking place, and if we are to use the opportunities which they and the destruction due to air attack afford, some of the thinking involved in planning must be done now. Moreover, if we postulate as a material ideal the right of every man and woman to a healthy and beautiful environment, national as well as local planning is required.

Mr. Gibson accordingly advocates the formation of a committee, armed not merely with the knowledge already existing in the $\mathrm{P} \mathrm{E} \mathrm{P} \mathrm{report} \mathrm{and} \mathrm{the}$ report of the Barlow Commission, but also with the widest powers possible in war-time. No vested interest should be allowed to withhold from it information necessary for the preparation of a longterm plan. The keynote of this committee and of the local town-planning committees linked with it should be decentralization and regeneration-an attempt to reverse the present tendency and encourage a network of clean, healthy towns.

This suggestion would appear to have been adopted in essence by Lord Reith, who, in the House of Lords on February 26, stated that he was inviting a dozen or twenty individuals who had special experience to assist him, and to be associated from the beginning in a consultative capacity with the central planning and co-ordination of postWar physical reconstruction. Lord Reith also proposes to use the resources of other departments and to ask for the collaboration of professional and technical associations. An offer from the council of the Royal Institute of British Architects has 
already been welcomed by him. Lord Reith also stated that he has been authorized to proceed on the assumption that the principle of planning would be accepted as national policy, and that some central planning authority would be required. which would proceed on a positive policy for agricultural and industrial development and transport, and that some services would require treatment on a national basis, some regionally, and some locally.

Besides this question of national planning and all that is involved in the use of the land, and the subordination, for the good of the community, of private interests to public ones, there is an immense field for technical development. Too seldom does the architect or builder remember that it is his duty to-day to make his design-whether house or public building or factory - suit the needs of the people, and achieve beauty with the use of all the technical advances at his disposal. Mr. Gibson was able to point to the way in which developments and new ideas are being incorporated in houses now being constructed in Coventry, and he urged that to build for permanence is a mistake, limiting or hampering the satisfaction of the needs of to-morrow.

These are revolutionary ideas to many, but it is only by recognizing their force that we can hope to utilize to the full the new knowledge and materials which science is placing at the disposal of the building industry to satisfy the cultural and rsthetic needs of the community, as well as its material needs. They may involve departure from traditional practice and organization, and $\mathrm{Mr}$. Gibson himself advocates the establishment now of a committee of architects, to face these problems, with representatives from aircraft works both on the design and organization sides, and of the Building Research Station, so that the new forms of construction may be ready when the call comes and the transition of factories from war-work to the production of houses, using the light, efficient and beautiful materials which are employed with such efficiency and economy in aircraft, may be facilitated. Moreover, the work of the architect, the planner and the engineer must go hand-inhand, with a clear definition of the spheres in which each can best serve the community. For the building industry, Mr. Gibson visualizes a new type of educational centre-a combination of technical school, architectural school and townplanning department, in which students would learn to handle and work on materials in the early years and would be sifted out in accordance with their talents and ability, the most gifted becoming planners of the future environment.

\section{INDEX LONDINENSIS}

Index Londinensis to Illustrations of Flowering Plants, Ferns and Fern Allies

Supplement for the Years 1921-35. Prepared under the auspices of the Royal Horticultural Society of London at the Royal Botanic Gardens, Kew, by W. C. Worsdell, under the direction of Sir Arthur W Hill. Part 1 : A-H. Pp. vii + 497. Part 2: I-Z. Pp. iv +515 . (Oxford: Clarendon Press; London: Oxford University Press, 1941.) 2 vols., $£ 1010 s$. $0 d$. net.

THE appearance of this supplement to "Index Londinensis" is an event of more than ordinary interest to all botanists and scientific horticulturists. Its production in time of war in the same style and with the same high standard of excellence which marked the original work will be regarded as a fine achievement.

The first and for many years the only work of its kind was Pritzel's "Index Iconum Botanicarum", published in 1855. This provided a convenient alphabetical register of illustrations of flowering plants and ferns selected from botanical literature from about the time of Linnæus onwards. During the latter part of the nineteenth century, however, the rapid progress of botanical science and the increasing use of illustrations in botanical writings made it desirable that Pritzel's "Index" should be revised and brought up to date. This was a task of no small magnitude, but thanks to the enterprise and support of the Royal Horticultural Society the work was successfully accomplished, and the six volumes of "Index Londinensis" were issued at intervals between 1929 and 1931, under the editorship of the late Dr. O. Stapf of the Kew Herbarium. The work was an emended and enlarged edition of Pritzel's original register, which now possesses only historic interest, and included all references to figures of flowering plants and ferns down to the end of the year 1920 .

Although the six volumes of "Index Londinensis" were estimated to contain nearly five hundred 